BIP: Jurnal Bahasa Indonesia Prima Vol. 3, No. 2, 2021, September 2021, PP.

\title{
ANALISIS TINDAK TUTUR DIREKTIF DALAM PROSES TAWAR MENAWAR DI DESA CICINDE UTARA BANYUSARI KARAWANG
}

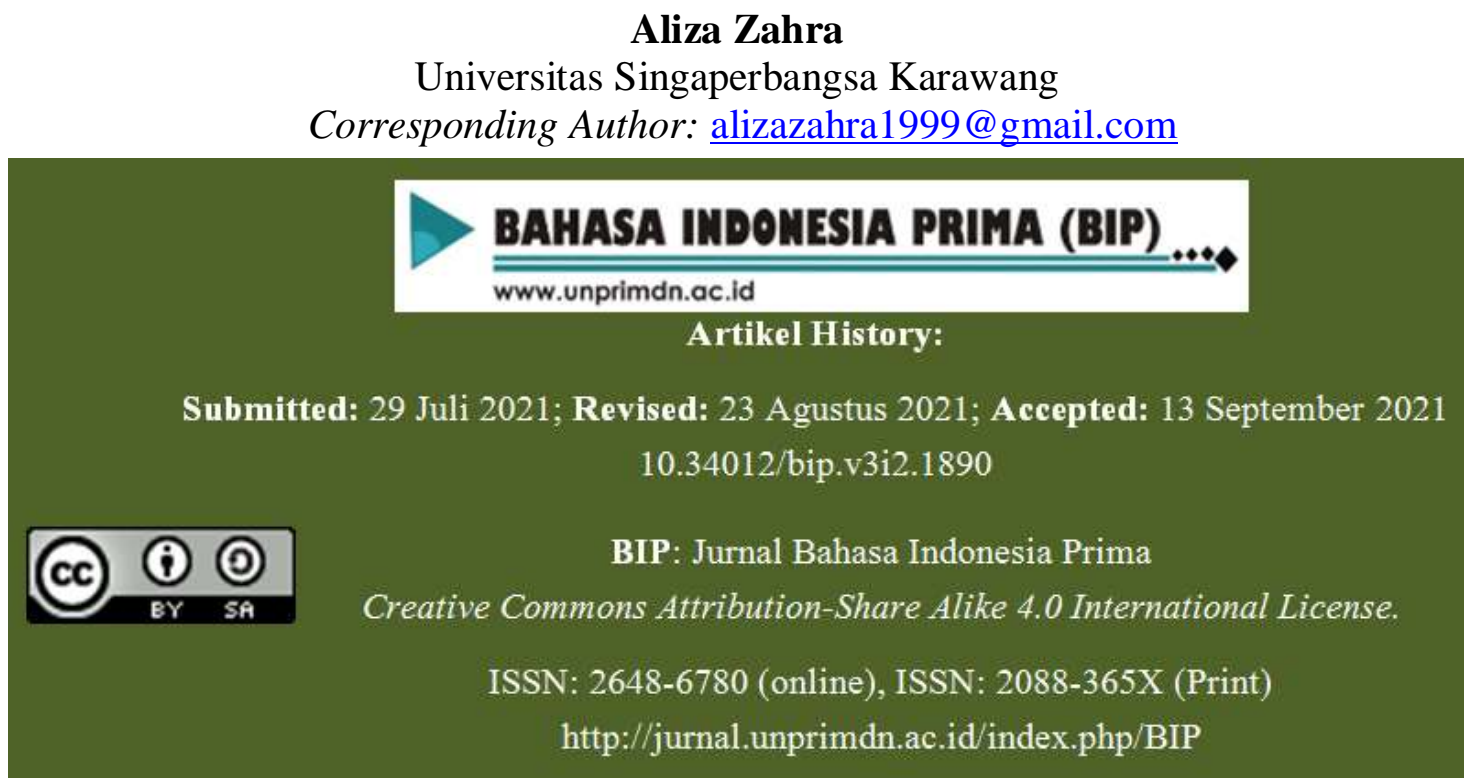

Abstrak-Tujuan penelitian ini untuk mendeskripsikan bentuk tindak tutur direktif dan fungsi tindak tutur direktif dalam proses tawar menawar serta implementasinya sebagai bahan ajar teks negosiasi. Metode yang digunakan adalah deskriptif kualitatif. Sumber data dalam penelitian ini adalah tindak tutur masyarakat Desa Cicinde Utara, Banyusari, Karawang. Kemudian pada tahap pengumpulan data menggunakan teknik observasi. Dalam teknik analisis data menggunakan reduksi data, penyajian data, penyimpulan dan verifikasi, keimpulan akhir. Dengan begitu hasil akhir dalam penelitian ini menghasilkan 40 tuturan dari 10 data yang diambil dan menghasilkan 4 jenis tindak tutur direktif yang diantaranya : tindak tutur direktif menyarankan 18 tuturan, tindak tutur direktif melarang 7 tuturan, tindak tutur memerintah 3 tuturan, dan tindak tutur direktif mengkritik 12 tuturan.

Kata kunci: pragmatik, tindak tutur direktif.

Abstract-The aim of this research is to describe the form of directive speech acts and directive speech fungsions in the bergaining process and their imolementation as teaching materials for negotiating texts. The method used is descriptive qualitative. The source of data in this study is the speech aacts of the people of North Cicinde Village, Banyusari, Karawang. Then at the data collection satge using observation techniques. In data analysis techniques using data reduction, data prasetation, conclusions and levers. Final conclusion. Thus, the final results in this study resulted in 40 utterances from 10 data taken and resulted in 4 types of directive speech acts which include: direktive speech acts suggesting 18 speeches, prohibitive direktive speech acts 7 speeches, commanding speech acts 3 speeches, and critical direktive speech acts 12 utterances.

Keyboard: pragmatic, tindak tutur directif. 


\section{A. Pendahuluan}

Di dalam ilmu linguistik yang mengkaji kebahasaan yang berdasarkan konteks adalah pragmatik.Pragmatik merupakan suatu ilmu yang mempelajari struktur bahasa yang digunakan dalam berkomunikasi. Selaras dengan pendapat Leech (dalam Rohmadi 2017: 2) yang mengemukakan bahwa pragmatik mempelajari bagaimana bahasa digunakan dalam komunikasi, dan bagaimana pragmatik menyelidiki makna sebagai konteks, bukan sebagai sesuatu yang abstrak dalam komunikasi. Adapun pendapat ahli lain menurut Wijana, (1996: 1) menjelaskan bahwa pragmatik adalah cabang ilmubahasa yang mempelajari struktur bahasa secara eksternal, yakni bagaimana penggunaan satuan kebahasaan itu digunakan dalam komunikasi. Dengan kata lain pragmatik merupakan telaah mengenai makna ujaran sesuai dengan konteks dan situasi ujaran. Di dalam situasi tersebut terdapat suatu peristiwa tutur. Peristiwa tindak tutur merupakan bentuk yang menjadi dasar bagi kegiatan komunikasi. Peristiwa tutur merupakan terjadinya suatu interaksi yang melibatkan dua pihak antara penutur dan mitra tutur yang bertujuan unuk melihat suatu makna dan tujuan pada tuturan tersebut. Di dalam peristiwa tutur terdapat tindak tutur yang digunakan oleh penutur dan mitra tutur. Menurut Yule (dalam Wibowo, 2018: 56) mendefinisikan tindak tutur "as the action perfomedby a speaker with an utterance" yang diterjemahkan sebagai berkut: sebagai tindakan yang dilakukan oleh penutur dengan sebuah tuturan. Adapun pendapat lain menurut Chaer (dalam Rohmadi 2017: 32) yang menyebutkan bahwa tindak tutur (speech act) adalah gejala indvindu yang bersifat psikologis dan keberlangsungannya ditentukan oleh kemampuan bahasa si penutur dalam menghadapi situasi tertentu. Jadi tindak tutur dapat dikatakan sebagai bentuk ujaran dalam berinteraksi.

Tindak tutur memiliki beberapa jenis yang dikemukakan oleh Searle (dalam Wibowo, 2018: 8) yang menyatakan bahwa ada 3 jenis tindakan yang dapat diwujudkan oleh seorang penutur, yakni tindak lokusi (locutionary act), tindak ilokusi (ilocuttionary act), dan tindak perlokusi (perlocutionary). Berdasarkan ilmu pragmatik ada tiga jenis tindakan yang dapat diwujudkan oleh seseorang penutur untuk melakukan komunikasi diantaranya, lokusi, ilokusi, dan perlokusi. Menurut Wijana, (1996:17) menjelaskan tindak tutur lokusi adalah tindak tutur untuk menyatakan sesuatu. Tindak tutur ini bermaksud semata-mata untuk memberikan suatu informasi untuk melakukan sesuatu, dan mampu mempengaruhi lawan bicaranya. Tindak tutur ilokusi digunakan dalam sebuah tuturan untuk melakukan sesuatu. Menurut Wijana, (dalam Wibowo, 2016: 25) tindak tutur ilokusi yaitu tindak tutur yang mengandung maksud yang berkaitan dengan siapa bertutur kepada siapa, kapan, dan dimana tindak tutur itu dilakukan. Selanjutnya mengenai klasifikasi tindak tutur menurut Yule, (2006: 92) mencantumkan 5 jenis fungsi umum yang ditunjukan oleh tindak tutur; deklarasi, representatif, ekspresif, direktif, dan komisif. Dan terakhir ada tindak tutur perlokusi yang diartikan sebuah tuturan yang digunakan dalam sebuah komunikasi yang seringkali mempunyai daya pengaruh atau bisa disebut dengan perlocutionary force. Menurut Wijana, (dalam Wibowo, 2018: 25) tindak tutur perlokusi adalah tindak tutur yang pengaturannya dimaksud untuk memengaruhi lawan bicara. Jenis 
tindak tutur ini dapat menimbulkan pengaruh secara disengaja atau tidak di senagaja yang dikreasikan oleh penuturnya.

Tindak tutur direktif merupakan bagian jenis tindak tutur ilokusi yang memiliki fungsi untuk mempengaruhi lawan bicara untuk melakukan sesuatu sesuai yang diutarakan penutur. Selaras dengan pendapat Wibowo (2018: 76) menyatakan bahwa tindak tutur direktif merupakan tuturan yang diujarkan oleh penutur dengan maksud agar mitra tutur berkenaan melakukan tindakan yang sesuai dengan apa yang dituturkan. Tindak tutur direktif memiliki beberapa jenis sebagai berikut: fungsi tindak tutur direktif melarang, memerintah, mengajak, menasihati,memperingatkan, mewajibkan, mengkritik, membuktikan, dan tindak tutur direktif menyarankan.

Tindak tutur dan peristiwa tutur ini menjadi dua gejala yang terdapat pada satu proses, yakni proses komunikasi, Chaer (dalam Wibowo, 2018: 7). Adapun pendapat lain menurut Hymes (dalam Wibowo, 2018: 25) mendeskripsikan sebuah teori yang di dalamnya terkandung unsur-unsur konteks tindak tutur. Peristiwa tutur juga dapat dikatakan sebagai kegiatan interaksi sosial antara penutur dengan mitra tutur dengan menggunakan bahasa secara konvesional untuk mencapai suatu hasil yang akan dicapai. Unsur tersebut diakronimkan dengan S.P.E.A.K.I.N.G.

Konteks dalam pragmatik dapat diartikan sebagai bagian yang tidak dapat dipisahkan dengan "ujaran" yang bisa berwujud kalimat maupun uraian yang dapat memperkuat kejelasan suatu makna situasi yang berkaitan dengan proses kejadian. Menurut Wibowo (2018: 24-25) menyebutkan bahwa Konteks adalah lingkungan di sekitar tuturan yang memungkinkan peserta tutur untuk berinteraksi dalam peristiwa komunikasi dan membuat bentuk kebahasaan yang digunakan dalam interaksi itu dapat dimengerti.

Dalam suatu komunikasi memiliki maksud dan tujuan yang berbeda-beda, dapat dilihat bagaimana seseorang menyampaikan suatu pemikiran melalui ujaran dengan cara berpikiran jernih sehingga tidak mengeluarkan sesuatu perkataan yang dapat menyinggung lawan bicara. Dalam berinteraksi juga perlu adanya arahan serta aturan agar terciptanya suatu komunikasi yang baik dan susuai kaidah yang berlaku. Salah satunya dengan cara memahami bagaimana fungsi serta makna setiap perkataan yang di ujarkan, serta dapat mengarahkan sesuai dengan maksud tujuan yang diujarakan. Hal ini harus diperhatikan karena dapat menciptakan suatu keindahan atau seni dalam berbahasa, jika seseorang telah memahami bagaimana berbahasa dengan baik dalam berkomunikasi dengan begitu dapat dikatakan bahwa ia telah melakukan komunikasi secara optimal, maka dari itu hal ini akan dijelaskan secara rinci bagimana penggunaan bahasa yang digunakan oleh masyarakat Desa Cicinde Utara dalam proses tawar menawar dengan menggunakan pendekatan pragmatik yang memfokuskan pada analisis tindak tutur direktif.

Hal itu berkaitan dengan peristiwa yang kerap kali ditemui oleh peneliti pada saat interaksi sosial dengan masyarakat dalam proses tawar-menawar di desa Cicinde Utara, Banyusari, Karawang untuk melakukan bernegosiasi dalam konteks jual-beli pakaian terbukti bahwa masyarakat setempat mengutarakan keinginan untuk menurunkan harga barang yang berlebihan serta mengingikan barang 
yang sesuai pembeli dengan harga yang murah dan kualitas yang bagus sertamasyarakat tidak memahami etika berbahasa dalam bernegosiasi. Berdasarkan latar belakang masalah yang telah diuraikan diatas maka tujuan penelitian tersebut untuk mendreskripsikan wujud tindak tutur direktif, fungsi tindak tutur direktif, dan hasil analisis tindak tutur direktif dalam proses tawar menawar di Desa Cicinde Utara, Banyusari, Karawang.

Sebelumnya penelitian ini sudah pernah dilakukan dan dijadikan sebagai panduan dan akan mengikuti jejak penelitian sebelumnyaoleh penulis yaitupenelitian dari Nisa Afifah dengan judul penelitian Tindak Tutur Direktif dan Kesantunan Berbahasa Pemasar Kepada Konsumen Dalam Penawaran Program Solusi Haji dan Umrah di PT Arminareka Perdana Cabang Solo: Sebuah Pendekatan Pragmatik. Pada penelitian sebelumnya memiliki persamaan dengan penelitian yang akan dilakukan oleh penulis yaitu dari pemilihan beberapa teori, menggunakan metode deskriptif kualitatif, menggunakan metode pengumpulan data melalui rekaman namun yang membedakan yaitu pada peneliti sebelumnya menggunakan teknik simak bebas libat cakap (SBLC) sedangkan untuk penelitian peneliti menggunakan interaksi langsung dengan objek, dan yang menjadi pembeda adalah pada teknik analisis data.

\section{B. Metode Penelitian}

Penelitian ini adalah penelitian kualitatif dengan metode deskriptif. Karena hasil akhir dalam penelitian ini adalah berupa deskripsi mengenai tuturan lisan masyarakat pada saat proses tawar menawar. Menurut Bogdan dan Taylor (dalam Sujarweni, 2020: 6) menjelaskan bahwa penelitian kualitatif adalah salah satu prosedur penelitian yang mengasilkan data deskriptif berupa ucapan atau tulisan dan perilaku orang-orang yang diamati. Objek penelitian ini berupa bahasa lisan atau tuturan. Kemudian subjek dalam penelitian ini adalah masyarakat Desa Cicinde Utara, Banyusari, Karawang. Pada saat pengumpulan data menggunakan teknik observasi partisipatif yang dibantu dengan handphone untuk merekam situasi yang terjadi di lapangan. Peneliti akan mengambil 10 data dari ujaran lisan dalam transaksi jual beli yang mana peneliti berperan sebagai penjual pakaian dan masyarakat setempat berperan sebagai pembeli atau konsumen. Dari data tersebutlah peneliti menganalisis tindak tutur direktif dengan menggunakan reduksi data, penyajian data, penyimpulan dan verifikasi, keimpulan akhir.

\section{Hasil dan Pembahasan}

Berkaitan dengan data yang di dapatkan dalam penelitian ini menghasilkan 4 jenis tindak tutur direktif yang diantaranya : tindak tutur direktif menyarankan, tindak tutur direktif melarang, tindak tutur memerintah, dan tindak tutur direktif mengkritik.

\section{a. Data Tindak Tutur Menyarankan}

Tindak tutur menyarankan adalah jenis tindak tutur yang makna ilokusinya memberikan sebuah saran atau memberikan suatu anjuran kepada lawan tutur. Tuturan yang bermaksud menyarankan yang ditemukan sebanyak 18 tuturan. Sebagai contoh tuturan menyarankan sebagai berikut :

Keterangan : Peneliti berperan sebagai penjual dan masyarakat desa Cicinde Utara sebagai pembeli

Konteks tuturan : dalam percakapan ini dilakukan oleh Salwa berusia 17 tahun pada hari minggu, 20 Juli 2021 pukul 16:00 WIB. Pada percakapan tersebut menunjukan Salwa sedang mengutarakan 
sebuah tuturan yang bersifat memberikan saran kepada penjual. Dan tidak membeli pakaian yang ditawarkan oleh penjual.

\section{Bentuk tuturan :}

Pembeli : "Tapi tong mahal-mahal nya, Teh".

"Tapi jangan mahal-mahal yah, Teh".

Penjual: "Nya tos kalem ka Awa mah, komo k tatangga mh gampang”. "Ya sudah santai ke Awa mah, apalagi ke tetanggan mah gampang".

Fungsi tuturan: Bertujuan untuk memberi saran kepada penjual agar tidak memberikan harga pakaian yang terlalu tinggi, kalimat tersebut dapat dibuktikan dengan kata "tapi" yang artinya pembeli ingin membeli sebuah produk yang ditawarkan dengan catatan tidak memberikan harga yang terlalu tinggi.Dengan begitu kalimat tersebuttermasuk jenis tindak tutur "Menyarankan".

\section{b. Data Tindak Tutur Melarang}

Tindak tutur direktif melarang merupakan suatu tindakan yang memiliki tjuan untuk memperingatkan kepada lawan tutur untuk tinda melakukan sesuatu atau memperbolehkan kepada lawan tutur. Tuturan yang bermaksud melarang yang ditemukan sebanyak 7 tuturan. Sebagai contoh tuturan melarang sebagai berikut :

Keterangan : Peneliti berperan sebagai penjual dan masyarakat desa Cicinde Utara sebagai pembeli.

Konteks tuturan : dalam percakapan ini dilakukan oleh Anita berusia 22 tahun pada hari Minggu, 22 Mei 2021 pukul 15:00 WIB. Pada percakapan tersebut menunjukan bahwa Anita sedang mengutarakan sebuah tuturan yang bersifat melarang kepada penjual agar tidak mengambil keuntungan yang terlalu tinggi.
Pembeli membeli sebuah pakaian tunik wanita berbahan plisket.

\section{Bentuk tuturan :}

Pembeli :

"Euntong seueur teuing
nyandak batina".
"Jangan terlalu banyak
ambil untungnya".
"Heunteu, entos hargi pas".
"Enggak, sudah harga pas".

Fungsi tuturan : Pada tuturan tersebut bertujuan agar penjual tidak mengambil keuntungan yang terlalu besar. Yang dapat ditandai penggunaan kata "Euntong" yang berasal dari bahasa sunda yang memiliki arti "jangan" Dengan demikian kalimat tersebut termasuk ke dalam tindak tutur "Melarang".

\section{c. Data Tindak Tutur Memerintah}

Tindak tutur direktif memerintah adalah tindak tutur yang makna ilokusi bermasuk untuk memberikan suruhan kepada lawan tutur. Tuturan yang bermaksud memerintah yang ditemukan sebanyak 3 tuturan. Sebagai contoh tuturan memerintah sebagai berikut :

Keterangan : Peneliti berperan sebagai penjual dan masyarakat desa Cicinde Utara sebagai pembeli.

Konteks tuturan : pada percakapan ini dilakukan oleh Ibu Ema berusia 35 Tahun pada hari Minggu, 13 Juni 2021, pukul 15:30 WIB. Pada percakapan tersebut Ibu Ema mengutarakan sebuah tuturan yang bersifat suruhan untuk dibawakan sebuah celana laki-laki kepada penjual. Di samping itu Ibu Ema membeli sebuah pakaian tunik berbahan katun rayon.

\section{Bentuk tuturan :}

Pembeli: "Cik mawa calana lalaki atuh".

"Cik bawa celana laki-laki dong".

Penjual : “Naon? nu Hidnu? Hayu”. 


\section{"Apa? Yang Hidnu? \\ Hayu”.}

Fungsi tuturan: Yang berarti mengutarakan sebuah perintah agar penjual melakukan hal yang diminta oleh pembeli dengan cara membawakan sebuah celana yang dibuktikan dengan kata "bawa". Dengan demikian kalimat tersebut termasuk ke dalam tindak tutur "Memerintah".

\section{d. Data Tindak Tutur Mengkritik}

Tindak tutur direktif mengkritik adalah tindak tutur yang bertujuan untuk mengemukakan kritikan seperti memberikan tanggapan atau kecaman kepada lawan tutur. Tuturan yang bermaksud mengkritik yang ditemukan sebanyak 12 tuturan. Sebagai contoh tuturan mengkritik sebagai berikut :

Keterangan :

Peneliti berperan sebagai penjual dan masyarakat desa Cicinde Utara sebagai pembeli.

Konteks tuturan : pada percakapan ini dilakukan oleh Ibu Erni berusia 40 Tahun pada hari Minggu, 13 Juni 2021, pukul 15:30 WIB. Pada percakapan tersebut Ibu Erni mengutarakan sebuah tuturan yang bersifat kritikan terhadap pakaian yang dibawakan oleh pnjual. Di samping itu Ibu Ema membeli sebuah pakaian tunik berbahan katun rayon.

Bentuk tuturan :

Penjual: "Saetik deui teh hayu, Tah ieu acuk rajut teh".

"Sedikit lagi kak ayo, nah ini baju rajut kak".

Pembeli : "Kos nu panas bahan rajut kieu teh".

"Sepertinya panas bahan nya".

"Apa? Buat Hidnu?

Boleh".

Fungsi tuturan: Tuturan tersebut memiliki maksud serta tujuan untuk menyampaikan sebuah kritikan pada pakaian dengan bahan rajut yang terasa panas jika dipakai, dapat dibuktikan dengan kalimat "kos nu panas bahan rajut teh". Dengan begituu ujaran tersebut dapat dikatakan sebagai fungsi tindak tutur direktif "Mengkritik".

\section{Kesimpulan}

Dari hasil penelitian ini mengenai wujud tindak tutur dan fungsi tindak tutur direktif menunjukan bahwa penggunaan bahasa yang digunakan oleh masyarakat pada saat proses tawar menawar memiliki tujuan serta maksud untuk menyatakan keinginan pembeli yang lebih di dominasi dalammenurunkan harga sebuah produk yang ditawarkan oleh penjual, sehingga pada saat proses tawar menawar berlangsung masyarakat tidak banyak yang memahami bagaimana penyampaian bahasa yang baik pada saat bernegosiasi. Pada saat melakukan penelitian menemukan beberapa jenis tindak tutur direktif seperti tindak tutur direktif menyarankan, memerintah, melarang dan mengkritik. Berdasarkan hasil analisis diatas dalam proses tawar tawar menawar harus memperhatikan kode etik yang berlaku agar tidak menimbulkan singgungan antara pembeli dan penjual.

\section{Catatan}

1. Artikel ini disusun berdasarkan hasil skripsi penulis dengan pembimbing I Wienike Dinar Pratiwi, S.Pd., M.Pd.

2. Artikel ini disusun berdasarkan hasil skripsi penulis dengan pembimbing II Dr. Een Nurhasanah, SS., MA.

\section{Daftar Pustaka}

Sujarweni, V. Wiratna. 2020. Metode Penelitian.

Yogyakarta: Pustakabarupress. 
BIP: Jurnal Bahasa Indonesia Prima Vol. 3, No. 2, 2021, September 2021, PP.

Wibowo. Setiawan Edi. 2018.

Etnopgragmatik Bingkai Budaya

Kiai Jawa. Jawa Tengah: CV.

Sarnu Untung.

Rohmadi. 2017. Pragmatik Teori dan Analisis. Surakarta: Yuma Pustaka.

Sugiono. 2018. Metode Penelitian, Kuantitatif, Kualitatif, dan R\&D. Bandung: Alfabeta.cv.

Wijana, Dewa Putu, I. 1996. Dasar-dasar Pragmatik. Andi: Yogyakarta 